\author{
INEEL/CON-04-01904 \\ PREPRINT \\ The Worker Exposure Failure Modes And \\ Effects Analysis
}

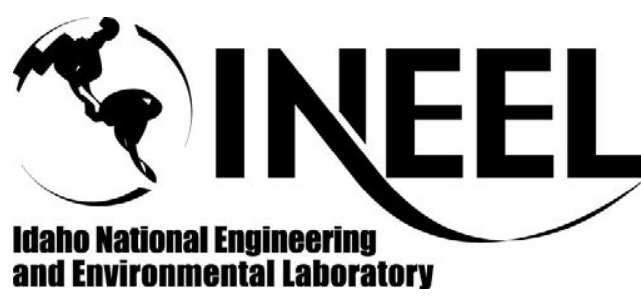

L. C. Cadwallader

September 14-16, 2004

\title{
Sixteenth Topical Meeting on the Technology of Fusion Energy
}

This is a preprint of a paper intended for publication in a journal or proceedings. Since changes may be made before publication, this preprint should not be cited or reproduced without permission of the author.

This document was prepared as an account of work sponsored by an agency of the United States Government. Neither the United States Government nor any agency thereof, or any of their employees, makes any warranty, expressed or implied, or assumes any legal liability or responsibility for any third party's use, or the results of such use, of any information, apparatus, product or process disclosed in this report, or represents that its use by such third party would not infringe privately owned rights. The views expressed in this paper are not necessarily those of the U.S. Government or the sponsoring agency. 


\title{
THE WORKER EXPOSURE FAILURE MODES AND EFFECTS ANALYSIS
}

\author{
L. C. Cadwallader \\ Idaho National Engineering and Environmental Laboratory, PO Box 1625, Idaho Falls, ID 83415-3860, Icc@inel.gov
}

The Worker Exposure Failure Modes and Effects Analysis (WE-FMEA) is a new approach to quantitatively evaluate worker risks from possible failures of co-located equipment in the complex environment of a magnetic or inertial fusion experiment. For next-step experiments such as the International Thermonuclear Experimental Reactor (ITER) or the National Ignition Facility (NIF), the systems and equipment will be larger, handle more throughput or power, and will, in general, be more robust than past experiments. These systems and equipment are necessary to operate the machine, but the rooms are congested with equipment, piping, and cables, which poses a new level of hazard for workers who will perform hands-on maintenance. The WE-FMEA systematically analyzes the nearby equipment and the work environment for equipment failure or inherent hazards, and then develops exposure scenarios. Once identified, the exposure scenarios are evaluated for the worker hazards and quantitative worker risk is calculated. Then risk scenarios are quantitatively compared to existing statistical data on worker injuries; high-risk scenarios can be identified and addressed in more detail to determine the proper means to reduce, mitigate, or protect against the hazard. The WE-FMEA approach is described and a cooling system maintenance example is given.

\section{INTRODUCTION}

Safety assessment techniques currently used by industrial safety professionals tend to be qualitative; they are used mainly to identify hazards and the personal protective equipment needed for deterministic protection against the hazards. This approach is typified by the 29CFR1910.134 technique that directs a walk-through of the workplace to identify task hazards. The foremost tool used for the qualitative approach is the Job Hazard Analysis (JHA) that deconstructs a task into its major parts or actions to identify the hazards of energy or hazardous material exposure. ${ }^{1,2}$ The JHA is quite useful in developing safety procedures for tasks and recommending personal protective equipment for workers to use during performance of tasks. For the state-of-theart JHA, the industrial safety professional judges the degree of hazard subjectively and protective measures are adopted based on the safety professional's intuition, guidance from best industry practice, regulation, or some combination of all of these. The JHA can also identify the hazard for follow-up detailed analysis.

The JHA is a proven analysis tool that has worked well for many situations that require workplace safety assessment. $^{3}$ The JHA has been used for decades; however, the JHA focuses on the task the worker is performing. In a simple working environment, such as a large shop with few indirect or proximate hazards apart from the task at hand, the JHA performs well and gives a complete analysis of hazards. For example, in a manufacturing plant with defined work areas, workers have the primary concerns of overexertion, falls, tool handling injuries, hand wounds, cuts and pinches from moving parts, and impacts from work pieces; ${ }^{4}$ there are few secondary hazards of concern. In a complex working environment, such as a fusion experiment, a particle accelerator, or a power plant, there can be a number of other hazards peripheral to the task at hand. In such an environment, the workers access areas that pose multiple hazards from systems and equipment that are in close proximity to the workers, but are not part of the work to be performed. These nearby systems or equipment may or may not be de-energized. Such indirect or proximate hazards are not typically included in the JHA. The JHA may address general issues about the work environment, such as high room air temperature or radiation exposure, but this is not sufficient to provide comprehensive worker protection in a complex fusion facility.

Other worker safety assessment methods have been developed in the past decade, primarily to evaluate worker risks during environmental cleanup tasks. ${ }^{5-8}$ The worker safety methods developed in the 1990's for environmental cleanup focus on the consequence assessment aspects of worker exposure to the process hazards, namely radioactive, toxicological, and mixed wastes that are handled and packaged in remediation work. The safety concerns in cleanup work arise from the task at hand, such as dealing with flammable gases in waste drums, potential fission criticality of the waste materials, and hazardous material exposure during handling. Once again, the focus is on the primary hazards 
facing the workers. Perhaps the most definitive publication on worker safety methods is HarmsRingdahl; ${ }^{9}$ it also focuses on the primary hazards of the task at hand. The new worker safety approach described here augments these past approaches since its focus is on peripheral or secondary hazards nearby rather than the primary hazards of the energy sources and hazardous materials in the task at hand. While these primary hazards usually have the greatest influence on worker safety, if the workers are properly following their procedures and using personal protective equipment - as we expect in a first of a kind fusion facility - then secondary hazards that have not been analyzed or guarded against can have the greatest influence on their safety.

\section{WORKER EXPOSURE FMEA METHOD}

To address the hazards of proximate systems and equipment, a modification to the system-level Failure Modes and Effects Analysis (FMEA) ${ }^{10}$ is proposed. The FMEA is already a proven, respected technique in the many industries. ${ }^{11-14}$ Fusion designs have also made good use of the FMEA. ${ }^{15}$ The analysis tool is known for its systematic evaluation and ranking of faults that can occur in the system under study. The traditional FMEA is applied to all the major components of a given system to be evaluated, even when the system components are in multiple rooms or floors of a facility. To address worker safety, the system-level FMEA has been modified to identify all of the components posing potential hazards to the worker. For this application, the system-level FMEA approach is used not with a system component boundary; instead the Worker Exposure FMEA (WE-FMEA) analyzes only the components that are near the worker's location (i.e., within the same room or perhaps within $\sim 10 \mathrm{~m}$ of the worker). The set of components close to the worker will almost always reside in a number of different systems; the set also includes those distant components whose failure can directly affect the worker's location, such as ventilation fans. Therefore, WE-FMEA treats the proximate components from a number of systems, instead of the components from one entire system. The WEFMEA further alters the traditional system FMEA to only consider equipment failure modes that can present an immediate hazard to the worker rather than all known equipment failure modes. Also, the WE-FMEA failure effects are the injury consequences to the worker rather than component failure effects to its parent system. The WE-FMEA uses the systematic nature of FMEA to identify hazardous events arising from component failures and records a preliminary quantification of the probability of the component failures. With the type of industrial injury and the probability of component failure identified, the risk to the worker can be calculated.

Personnel injuries can vary a great deal in the actual damage inflicted. Classifying injuries can be performed based on the part of the body affected, the severity of the injury, the ability to heal or recover from the injury, physical impairments that may result from the injury, or other factors. Due to this variety of classifications, typifying injuries for assessing the human injury consequences of a component failure is problematic. For this paper, the 'Abbreviated Injury Scale' from emergency medicine ${ }^{16}$ has been used as a starting point to categorize injury severity. Potential injuries are qualitatively ranked as one of six levels, defined here as:

1. Minor Injury (MI): first aid cases or injuries that do not result in lost work days, the worker is released to return to the job after receiving aid (i.e., contusions, abrasions, lacerations, mild sprains, etc.);

2. Moderate Injury (MoI): cases where the worker leaves the job to obtain medical treatment but does not require emergency medical help (large or deep lacerations, muscle strain, sprains, small burn areas, etc.). A MoI may result in lost work time;

3. Serious Injury (SI): worker injuries that require emergency medical help and result in one or more lost work days (individual bone fractures, mild concussion such as from a standing fall to the floor, modest area burns, very large lacerations, penetrating wound with mild organ damage, some blood loss, etc.);

4. Severe Injury (SeI): worker injuries that require immediate emergency medical help and result in perhaps a week or longer of lost work days (moderate area burns, many broken bones from a fall from modest height, concussion, mild eye damage, moderate organ damage, large blood loss, etc.);

5. Critical Injury (CI): worker injuries that require immediate emergency medical help, results in weeks of lost work days, and may not ever return to that type of work again (such as deep or large area burns, electric shock, severe organ damage, memory loss from asphyxiation, eye loss, injuries from a fall from height, very large blood loss, etc.);

6. Unsurvivable or Fatal Injury (FI): the sustained injuries result in immediate fatality or are the direct cause of delayed fatality (such as organ damage to the point of organ failure, brain trauma, extreme blood loss, high percentage body burns, electrocution, fatal fall, etc.).

The WE-FMEA analysis steps are to first identify the maintenance or other plant activity to be analyzed and the work location within in the facility. Next, the literature should be surveyed to determine the types of hazards and injuries that have occurred when performing the same task or similar tasks in similar facilities; in this case, other fusion experiments, particle accelerators, or other facilities with a system similar to the one under consideration. Next, the personnel safety master logic diagram $^{17}$ or other methods, such as checklists, can be used to identify the types of energy sources and hazards in 
the vicinity of the worker's activity (maintenance, calibration, etc.). With this information, the pieces of equipment and their failure modes that could create local hazards in a $\sim 10 \mathrm{~m}$-diameter sphere around the worker are systematically identified. Next, any remote equipment necessary for worker protection that has not been addressed already in the JHA must be identified. Example equipment could include ventilating fans, ventilation dampers, chillers, area monitors, circuit breakers, lights, etc. These equipment items are recorded on a worksheet similar to a traditional FMEA worksheet. The worksheet entries are evaluated for these 'secondary risks' to the workers. If the secondary risks are low, no additional safety provisions are required. If the secondary risks are high, then the analyst must assess if any of the personal protective equipment (PPE) issued for primary hazard protection will offer some protection for the secondary hazard. If the PPE also protects the worker from secondary hazards, then the task is complete. If not, then the analyst must identify the additional means that are needed to mitigate or reduce the secondary risks by using engineering or administrative controls on the task. The WE-FMEA must be used in concert with a JHA or other worker task based assessment to determine the protective measures (buddy system, camera surveillance, radio, etc.) and protective equipment the worker will be using for protection from primary and secondary hazards.

\section{WE-FMEA EXAMPLE}

As an example of this method, the WE-FMEA is applied to a representative task of a yearly, 4-hour calibration of a cooling water instrument in the first wall (FW) cooling system of a magnetic fusion experiment. The cooling systems for the experiment use water, similar to the ITER design. The instrument maintenance task would be performed in a cooling system room that contains the main cooling equipment and piping for divertor and FW cooling. Fig. 1 shows a suggested room layout for the example task. Since fusion designers are aware that placing instrumentation in a high magnetic field can lead to inaccurate readings, there is an expectation that the magnetic field strength will not be high in the work area. Both cooling systems have piping, pumps, valves and heat exchangers near the worker's location. There is a residual radiation field from the activation in the coolant water. The coolant system equipment room also operates at a somewhat elevated temperature and with high noise due to the large pump motors, assumed to be in the 4 to $13 \mathrm{kV}$ size range. There may or may not be plasma heating conduits routed through the room, which presents the possibility that leakage electromagnetic radiation from the conduits could be present in the room. Design details of the room are not complete for this example; some assumptions have been made. The FW cooling system itself is assumed to have been "safed", that is, cooled down to room temperature and depressurized. This is a safety precaution for the personnel and it also serves as a calibration point in the instrument calibration process (i.e., "zeroing" the instrument). The adjacent cooling systems are assumed to be active since there must be active cooling for decay heat removal from the tokamak. Typical plasma operation could require the divertor cooling system to operate at $150 \mathrm{C}$ at $4 \mathrm{MPa}$; however, the cooling system might be operating at a reduced value when only removing decay heat. Even at reduced heat transfer conditions, the system will be pressurized to suppress coolant boiling. Perhaps the coolant parameters in decay heat removal mode will not create steam during a pipe breach event, but spraying $60 \mathrm{C}$ liquid water still constitutes serious burn and ocular hazards.

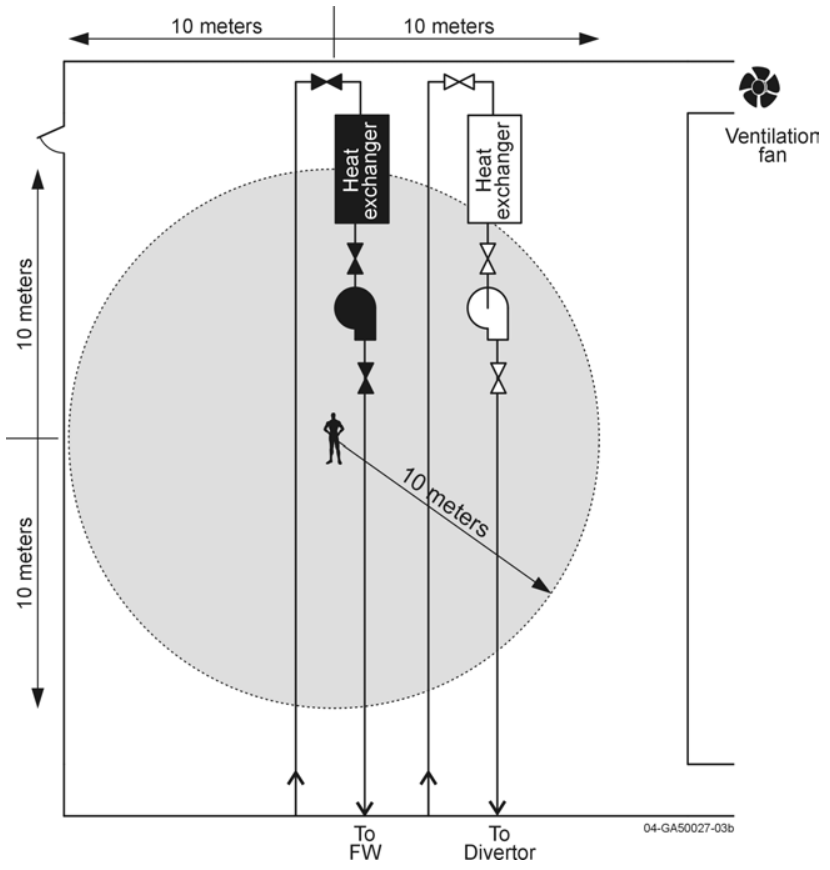

Fig. 1. Illustrative room layout for the WE-FEMA example.

Following the WE-FMEA steps outlined above, the US Department of Energy (DOE) Occurrence Reporting and Processing System database was searched for events related to pressure instruments. The results were several events of not securing power to the instrument before starting work, leaks and spills associated with the instrument work, safety issues of working at height, and some burns sustained from nearby piping. The first three concerns - securing power, handling coolant leaks/spills, and working at height - are expected to be addressed in the JHA. The fourth concern, burn injuries from nearby piping, is exactly the type of issue that the WE-FMEA can identify and a JHA may or may not identify because the primary work is on an instrument and pipe at room temperature. Calibrating the pressure instrument can also 
mean exposure to radiation in the coolant from activated corrosion products, and the potential for skin contamination if the FW coolant leaks. The JHA would probably specify anti-contamination clothing - gloves, tyvek coveralls, booties, possibly a hood, and some type of face shield to protect against splashing. The workers would probably not require breathing apparatus since the task is conducted at room temperature and pressure and is not expected to generate any gaseous or particulate emissions. If the workers are on a tall scaffold to access the pressure instrument, they will also have fall protection equipment specified.

The WE-FMEA example for FW cooling system instrument calibration is given in Table I. Several possible energy and hazardous material releases were identified when considering a generic equipment room. The piping in adjacent systems was evaluated based on an assumption that the worker is $>1 \mathrm{~m}$ outward from a break location. As a first approximation, the injury consequences are considered to decrease as the workers' distance from the breach increases; the $1 \mathrm{~m}$ is a distance that should protect against pressure jet effects. The WEFMEA shows that steam or hot water leaks could occur, albeit at a low probability over the time frame of the task. The expected anti-contamination clothing for this instrument calibration task is deemed inadequate to protect against high temperature and pressure water release, or steam release, in the area.

The American Petroleum Institute (API) has provided some worker safety guidance on steam releases and exposure. ${ }^{18}$ When modest pressure steam is released, the steam jet fans out and slows within about a meter from the break, and the steam cools to $100 \mathrm{C}$ just after exiting the breach. The steam also heats up the room air. At a concentration of $20 \%$ steam in the air, the steam/air mixture cools to about $60 \mathrm{C}$. Using $60 \mathrm{C}$ as the minimum temperature for human burn injury from steam/air exposure, the API determined the steam-affected areas around a breach location and developed simple relations to estimate these areas. For continuous steam leaks the affected floor area is calculated by the formula $\mathrm{A}=0.6(\mathrm{x})$, where $\mathrm{x}$ is the steam release rate in pounds/second, and $\mathrm{A}$ is floor area covered by $20 \%$ or more steam, in square feet. Presumably, the affected height is the floor-toceiling height. For our modeling purposes the floor area was assumed to be rectangular and centered around the break location. Considering water systems, the generally accepted leak rate is up to 50 gallons/minute, and pipe ruptures are greater than that value. ${ }^{19}$ As a first approximation, converting a 50 gallons/minute water leak into a steam leak is $\sim 3 \mathrm{~kg} / \mathrm{s}$. Using the API formula with this leakage gives $0.37 \mathrm{~m}^{2}$, or an affected floor area of $0.6 \mathrm{~m}$ by $0.6 \mathrm{~m}$. For the worker $>1 \mathrm{~m}$ distant from the pipe, there is no immediate threat, or no injury (NI). For a pipe rupture, what the API calls an instantaneous steam release, the affected area equation is $A=(63.317)\left(\mathrm{x}^{0.6384}\right)$, where $\mathrm{A}$ is the area in square feet and $\mathrm{x}$ is the release mass in pounds. A rupture release could begin at $\sim 3 \mathrm{~kg}$ but will typically be much larger, such as $455 \mathrm{~kg}$. For the $455 \mathrm{~kg}$ case, the affected area is about 22 by 22 meters. For this example, the $22 \times 22 \mathrm{~m}$ floor area will be the assumed value for pipe ruptures and shell breaches, such as pump bodies and valve bodies. The heat exchanger shell breach is assumed to allow a larger release and will therefore pose a higher hazard. The worker is assumed to be less than $10 \mathrm{~m}$ from adjacent system pumps, valves, and heat exchangers in the example.

Exposure to steam will result in thermal burns and steam inhalation injury, as well as activation product exposure. The severity of steam injury is related to the temperature of the steam, the duration of exposure, the distance of the worker from the source of the steam, and the ability of the worker to escape the steam. ${ }^{20}$ Burns are judged based on the percent of body surface area (BSA) affected, and the age of the injured person. ${ }^{20}$ For example, the 45 to 64 year-old age group results are: $10 \%$ BSA has a $\sim 1 \%$ mortality, $20 \%$ BSA has a $5 \%$ mortality, $30 \%$ BSA has a $15 \%$ mortality, $40 \%$ BSA has a $20 \%$ mortality, 50\% BSA has a $60 \%$ mortality, $60 \%$ BSA has an $80 \%$ mortality, $70 \%$ BSA has a $90 \%$ morality and higher BSAs have $100 \%$ mortality. The "rule of nines" is used by medical personnel to estimate BSA. An adult's arm is $9 \%$ of their BSA, the front and the back of the trunk of the body are each $18 \%$, and each leg is $18 \%$. The face is $9 \%$, and the crotch is $1 \%$. For an initial estimation, the closer a worker is to a steam leak, the greater the steam engulfment and the higher the BSA affected. As a first approximation, 70\% BSA and higher is assigned the FI level, 50-60\% BSA is CI, 30-40\% BSA is $\mathrm{SeI}, 10-20 \% \mathrm{BSA}$ is SI. Under $10 \% \mathrm{BSA}$, not only does the human body have high capacity to survive a burn, but medical science has advanced to aid the burn patient; no mortality is given. Inhaling steam usually creates pulmonary injuries that exacerbate the skin burn injuries. The medical viewpoint is that steam has more damage potential than hot, dry air. The additional heat deposition from inhaled steam leads to hypoxia, anoxia, edema, and shock. ${ }^{20}$ Hence, the medical community views steam as more dangerous than smoke or hot air; with the advances in burn care some medical personnel believe that inhalation injury to the lungs is the main cause of mortality in burn patients. ${ }^{21,22}$ The steam can damage lung tissues and lead to pulmonary congestion, edema and pneumonia in the lungs, complicating recovery from skin burn injuries. If the worker or workers are on a scaffold to work at height, evading a steam release is not possible in a timely manner. This was tragically shown to be the case when a steam pipe failed at the Oconee nuclear power plant in $1982 .^{23}$ 
TABLE I. Example WE-FMEA for FW cooling water instrument calibration.

\begin{tabular}{|c|c|c|c|c|c|c|}
\hline $\begin{array}{l}\text { Proximate } \\
\text { Component } \\
\text { and System }\end{array}$ & $\begin{array}{c}\text { Potential } \\
\text { Component } \\
\text { Failure Mode }\end{array}$ & $\begin{array}{c}\text { Potential Causes } \\
\text { of Component } \\
\text { Failure }\end{array}$ & $\begin{array}{l}\text { Potential } \\
\text { Hazards to } \\
\text { Workers }\end{array}$ & $\begin{array}{l}\text { Frequency of } \\
\text { Component } \\
\text { Failure }\end{array}$ & $\begin{array}{c}\text { Worker } \\
\text { Risk }\end{array}$ & $\begin{array}{c}\text { Comments / } \\
\text { Recommended } \\
\text { Preventive } \\
\text { Actions }\end{array}$ \\
\hline $\begin{array}{l}\text { Coolant piping } \\
\text { For Divertor }\end{array}$ & Piping leak & $\begin{array}{l}\text { Erosion-corrosion } \\
\text { corrosion, fatigue, } \\
\text { weld flaw }\end{array}$ & $\begin{array}{l}\text { Steam inhalation, } \\
\text { jet exposure, } \\
\text { rad. exposure }\end{array}$ & $\begin{array}{l}2.5 \mathrm{E}-10 / \mathrm{h}-\mathrm{m}, \\
4 \text { hour task, } \\
1.2 \mathrm{~m} \times 2 \text { lines. }\end{array}$ & 2.4E-09 NI & $\begin{array}{l}>1 \mathrm{~m} \text { distant worker is } \\
\text { not at risk from } 0.6 \mathrm{x} \\
0.6 \mathrm{~m} \text { leak. }\end{array}$ \\
\hline $\begin{array}{l}\text { Coolant piping } \\
\text { For Divertor }\end{array}$ & Piping rupture & $\begin{array}{l}\text { Embrittlement, } \\
\text { weld failure }\end{array}$ & $\begin{array}{l}\text { Steam immersion, } \\
\text { inhalation, rad. } \\
\text { exposure }\end{array}$ & $\begin{array}{l}2.5 \mathrm{E}-11 / \mathrm{h}-\mathrm{m} \\
4 \text { hour task, } \\
22 \mathrm{~m} \times 2 \text { lines. }\end{array}$ & 4.4E-09 CI & $\begin{array}{l}<10 \text { m distant worker is } \\
\text { at risk. 'Leak before } \\
\text { break' may warn } \\
\text { worker. }\end{array}$ \\
\hline $\begin{array}{l}\text { Coolant pump } \\
\text { For Divertor }\end{array}$ & $\begin{array}{l}\text { Pump casing } \\
\text { leak }\end{array}$ & $\begin{array}{l}\text { Erosion-corrosion, } \\
\text { corrosion, fatigue, } \\
\text { overstress }\end{array}$ & $\begin{array}{l}\text { Steam inhalation, } \\
\text { jet exposure, } \\
\text { rad. exposure }\end{array}$ & $\begin{array}{l}3.6 \mathrm{E}-05 / \mathrm{h} \\
4 \text { hour task. }\end{array}$ & 1.44E-04 NI & $\begin{array}{l}>1 \mathrm{~m} \text { distant worker is } \\
\text { not at risk from } 0.6 \mathrm{x} \\
0.6 \mathrm{~m} \text { leak. }\end{array}$ \\
\hline $\begin{array}{l}\text { Coolant pump } \\
\text { for Divertor }\end{array}$ & $\begin{array}{l}\text { Pump seal } \\
\text { failure, loss of } \\
\text { coolant accident }\end{array}$ & $\begin{array}{l}\text { Seal water flow } \\
\text { failure, vibration, } \\
\text { wear }\end{array}$ & $\begin{array}{l}\text { Steam inhalation, } \\
\text { rad. exposure }\end{array}$ & $\begin{array}{l}7 \mathrm{E}-08 / \text { pump-h, } \\
4 \text { hour task. } \\
\text { Assume } 22 \mathrm{~m} \text { x } 22 \mathrm{~m} \\
\text { affected. }\end{array}$ & 2.8E-07 SeI & $\begin{array}{l}<10 \text { m distant worker is } \\
\text { at risk. 'Leak before } \\
\text { break' may warn } \\
\text { worker. }\end{array}$ \\
\hline $\begin{array}{l}\text { Coolant pump } \\
\text { for Divertor }\end{array}$ & $\begin{array}{l}\text { Pump flywheel } \\
\text { thrown }\end{array}$ & $\begin{array}{l}\text { Shaft fatigue, } \\
\text { bearing seizure, } \\
\text { flywheel fatigue }\end{array}$ & $\begin{array}{l}\text { Exposure to } \\
\text { shrapnel }\end{array}$ & $\begin{array}{l}<1 \mathrm{E}-06 / \text { year } \\
\text { or } 1 \mathrm{E}-10 / \mathrm{h}, \\
4 \text { hour task. }\end{array}$ & 4E-10 MoI & $\begin{array}{l}\text { Assumed failure rate, } \\
\text { assumed injury severity }\end{array}$ \\
\hline $\begin{array}{l}\text { Coolant pump } \\
\text { For Divertor }\end{array}$ & $\begin{array}{l}\text { Pump impeller } \\
\text { thrown }\end{array}$ & $\begin{array}{l}\text { Shaft fatigue, } \\
\text { bearing seizure, } \\
\text { impeller fatigue, } \\
\text { impeller unbalance }\end{array}$ & $\begin{array}{l}\text { Exposure to } \\
\text { shrapnel, steam } \\
\text { immersion, } \\
\text { inhalation, rad. } \\
\text { exposure }\end{array}$ & $\begin{array}{l}<1 \mathrm{E}-06 / \text { year } \\
\text { or } 1 \mathrm{E}-10 / \mathrm{h} \text {, } \\
4 \text { hour task; assume } \\
22 \mathrm{~m} \text { x } 22 \mathrm{~m} \text { affected. }\end{array}$ & 4E-10 SI & $\begin{array}{l}<10 \mathrm{~m} \text { distant worker is } \\
\text { at risk }\end{array}$ \\
\hline $\begin{array}{l}\text { Coolant pump } \\
\text { for Divertor }\end{array}$ & $\begin{array}{l}\text { Pump motor } \\
\text { fire }\end{array}$ & $\begin{array}{l}\text { Insulation } \\
\text { breakdown, } \\
\text { foreign material } \\
\text { intrusion }\end{array}$ & $\begin{array}{l}\text { Exposure to } \\
\text { smoke, hot } \\
\text { combustion } \\
\text { products }\end{array}$ & $\begin{array}{l}1.8 \mathrm{E}-07 / \mathrm{h}, \\
4 \text { hour task. Assume } \\
\text { room fills w/smoke. }\end{array}$ & 7.2E-07 MoI & $\begin{array}{l}\text { Alarms for timely } \\
\text { evacuation }\end{array}$ \\
\hline $\begin{array}{l}\text { Coolant pump } \\
\text { for Divertor }\end{array}$ & Lubricant leak & $\begin{array}{l}\text { Fatigue cracking, } \\
\text { vibration }\end{array}$ & $\begin{array}{l}\text { Exposure to hot } \\
\text { lubricant, may also } \\
\text { be mist of toxic } \\
\text { material }\end{array}$ & $\begin{array}{l}1 \mathrm{E}-06 / \mathrm{h}, \\
\text { assumed value. } \\
4 \text { hour task. }\end{array}$ & 4E-06 SI & $\begin{array}{l}\text { Assumes use of } \\
\text { nonflammable lubricant, } \\
60 \mathrm{C}, \sim 0.4 \mathrm{MPa} \text {. Mist } \\
\text { is assumed to spread. }\end{array}$ \\
\hline $\begin{array}{l}\text { Coolant pump } \\
\text { for Divertor }\end{array}$ & $\begin{array}{l}\text { Noise of } \\
\text { operation }\end{array}$ & Normal operation & $\begin{array}{l}\text { Acoustic energy } \\
\text { exposure }\end{array}$ & $\begin{array}{l}1, \\
\text { ambient environment }\end{array}$ & $1 \mathrm{MI}$ & $\begin{array}{l}\text { Assume JHA specifies } \\
\text { hearing protection }\end{array}$ \\
\hline $\begin{array}{l}\text { Coolant pump } \\
\text { for Divertor }\end{array}$ & $\begin{array}{l}\text { Exhaust heat } \\
\text { from operation }\end{array}$ & Normal operation & $\begin{array}{l}\text { Exposure to } \\
\text { elevated room air } \\
\text { temperature }\end{array}$ & $\begin{array}{l}\text { 1, } \\
\text { ambient environment }\end{array}$ & $1 \mathrm{MI}$ & $\begin{array}{l}\text { Assume exposures in } \\
\text { task environments are } \\
\text { limited [e.g., ref. 24] }\end{array}$ \\
\hline $\begin{array}{l}\text { Heat Exchanger } \\
\text { for Divertor }\end{array}$ & Shell leak & $\begin{array}{l}\text { Erosion-corrosion } \\
\text { corrosion, fatigue, } \\
\text { weld flaw }\end{array}$ & $\begin{array}{l}\text { Hot water jet, } \\
\text { possible radiation } \\
\text { exposure }\end{array}$ & $\begin{array}{l}1 \mathrm{E}-08 / \mathrm{h}, \\
4 \text { hour task. }\end{array}$ & 4E-08 NI & $\begin{array}{l}>1 \mathrm{~m} \text { distant worker is } \\
\text { not at risk from } 0.6 \mathrm{x} \\
06 \mathrm{~m} \text { leak }\end{array}$ \\
\hline $\begin{array}{l}\text { Heat Exchanger } \\
\text { for Divertor }\end{array}$ & Shell rupture & $\begin{array}{l}\text { Erosion, } \\
\text { embrittlement, } \\
\text { weld failure }\end{array}$ & $\begin{array}{l}\text { Hot water release, } \\
\text { possible } \\
\text { rad. exposure }\end{array}$ & $\begin{array}{l}1 \mathrm{E}-10 / \mathrm{h}, \\
4 \text { hour task. } \\
\text { Assume } 22 \mathrm{~m} \text { x } 22 \mathrm{~m} \\
\text { affected. }\end{array}$ & 4E-10 FI & $\begin{array}{l}<10 \text { m distant worker is } \\
\text { fatally injured. 'Leak } \\
\text { before break' may warn } \\
\text { worker. }\end{array}$ \\
\hline $\begin{array}{l}\text { Coolant } \\
\text { instrument for } \\
\text { Divertor }\end{array}$ & Leak & Fatigue, weld flaw & $\begin{array}{l}\text { Steam inhalation, } \\
\text { jet, radiation } \\
\text { exposure }\end{array}$ & $\begin{array}{l}1 \mathrm{E}-07 / \mathrm{h}, \\
4 \text { hour task. }\end{array}$ & 4E-07 NI & $\begin{array}{l}>1 \mathrm{~m} \text { distant worker is } \\
\text { not at risk }\end{array}$ \\
\hline $\begin{array}{l}\text { Coolant } \\
\text { instrument for } \\
\text { Divertor }\end{array}$ & $\begin{array}{l}\text { Ejection under } \\
\text { pressure/rupture }\end{array}$ & $\begin{array}{l}\text { Fatigue cracking, } \\
\text { weld failure }\end{array}$ & $\begin{array}{l}\text { Exposure to debris } \\
\text { missile, steam } \\
\text { inhalation, } \\
\text { radiation exposure }\end{array}$ & $\begin{array}{l}\sim 1 \mathrm{E}-04 / \text { year } \\
\text { or } 1 \mathrm{E}-08 / \text { hour, } \\
4 \text { hour task. } \\
\text { Assume } \sim 10 \% \\
\text { chance worker is } \\
\text { struck. }\end{array}$ & 4E-09 SeI & $\begin{array}{l}10 \% \text { is an overestimate } \\
\text { of primary impact plus } \\
\text { ricochets. }\end{array}$ \\
\hline $\begin{array}{l}\text { Isolation valve } \\
\text { for Divertor }\end{array}$ & $\begin{array}{l}\text { Leak past the } \\
\text { stem }\end{array}$ & $\begin{array}{l}\text { Valve packing } \\
\text { wear, foreign } \\
\text { material intrusion } \\
\text { on valve stem }\end{array}$ & $\begin{array}{l}\text { Steam inhalation, } \\
\text { jet exposure, } \\
\text { radiation exposure }\end{array}$ & $\begin{array}{l}1 \mathrm{E}-06 / \mathrm{h} \\
4 \text { hour task. }\end{array}$ & 4E-06 NI & $\begin{array}{l}>1 \mathrm{~m} \text { distant worker is } \\
\text { not at risk from } 0.6 \mathrm{x} \\
06 \mathrm{~m} \text { leak }\end{array}$ \\
\hline $\begin{array}{l}\text { Isolation valve } \\
\text { for Divertor }\end{array}$ & $\begin{array}{l}\text { Valve body } \\
\text { rupture }\end{array}$ & $\begin{array}{l}\text { Erosion-corrosion, } \\
\text { corrosion, fatigue, } \\
\text { casting flaw }\end{array}$ & $\begin{array}{l}\text { Steam immersion, } \\
\text { inhalation, rad. } \\
\text { exposure }\end{array}$ & $\begin{array}{l}1 \mathrm{E}-10 / \mathrm{h}, \\
4 \text { hour task. } 22 \mathrm{mx} \\
22 \mathrm{~m} .\end{array}$ & 4E-10 SeI & $\begin{array}{l}<10 \mathrm{~m} \text { distant worker is } \\
\text { injured }\end{array}$ \\
\hline
\end{tabular}


TABLE I. Continued

\begin{tabular}{|c|c|c|c|c|c|c|}
\hline $\begin{array}{c}\text { Affective } \\
\text { Component } \\
\text { and System }\end{array}$ & $\begin{array}{c}\text { Potential } \\
\text { Component } \\
\text { Failure Mode }\end{array}$ & $\begin{array}{c}\text { Potential Causes } \\
\text { of Component } \\
\text { Failure }\end{array}$ & $\begin{array}{c}\text { Potential } \\
\text { Hazards to } \\
\text { Workers }\end{array}$ & $\begin{array}{c}\text { Frequency of } \\
\text { Component } \\
\text { Failure }\end{array}$ & $\begin{array}{c}\text { Worker } \\
\text { Risk }\end{array}$ & $\begin{array}{c}\text { Comments / } \\
\text { Recommended } \\
\text { Preventive } \\
\text { Actions } \\
\end{array}$ \\
\hline $\begin{array}{l}\text { Ventilation fan } \\
\text { for room } \\
\text { ventilation } \\
\text { system }\end{array}$ & $\begin{array}{l}\text { fails to continue } \\
\text { to run }\end{array}$ & $\begin{array}{l}\text { motor fault, drive } \\
\text { fault, blade } \\
\text { imbalance }\end{array}$ & $\begin{array}{l}\text { Exposure to } \\
\text { elevated room air } \\
\text { temperature }\end{array}$ & $\begin{array}{l}3 \mathrm{E}-05 / \mathrm{h} \\
4 \text { hour task }\end{array}$ & $1.2 \mathrm{E}-04 \mathrm{MI}$ & $\begin{array}{l}\text { May have redundant } \\
\text { ventilation system, } \\
\text { limits to work } \\
\text { environment } \\
\text { temperature [ref 24] }\end{array}$ \\
\hline $\begin{array}{l}\text { Ventilation } \\
\text { damper for } \\
\text { room } \\
\text { ventilation } \\
\text { system } \\
\end{array}$ & fails closed & $\begin{array}{l}\text { linkage fault, } \\
\text { solenoid failure }\end{array}$ & $\begin{array}{l}\text { Exposure to } \\
\text { elevated room air } \\
\text { temperature }\end{array}$ & $\begin{array}{l}3 \mathrm{E}-07 / \mathrm{h} \\
4 \text { hour task }\end{array}$ & $1.2 \mathrm{E}-06 \mathrm{MI}$ & $\begin{array}{l}\text { May have redundant } \\
\text { ventilation system, } \\
\text { limits to work } \\
\text { environment } \\
\text { temperature [ref 24] }\end{array}$ \\
\hline $\begin{array}{l}\text { Worker Risk } \\
\text { Summations }\end{array}$ & \multicolumn{6}{|c|}{ No Injury, NI $=1.5 \mathrm{E}-04 \quad \mathrm{MI}=1.0$} \\
\hline
\end{tabular}

Note: Failure rate values were taken from references 25-28.

Some of the failures in Table I could result in debris being expelled from rotating equipment, or ejection of objects under pressure. In enclosed concrete rooms that are traversed by piping, it is possible to ricochet debris from piping, structural columns, cable trays or the walls/floor. Thus, the probability of impact should be increased over the initial 'line-of-flight' impact probability that was coarsely estimated using a $2 \pi$ geometry at $10 \mathrm{~m}$ radius and then ratioing an assumed human profile area to the hemisphere area. There are very sophisticated means available to determine the probability of impact from such debris, and one such method has been used for the National Ignition Facility in the case of a large capacitor failure that emits debris. ${ }^{29}$ The level of detail of the example in this paper did not warrant analysis using a ricochet tracking computer code.

The results given in Table I are on a per worker basis, although the task may specify two workers to meet the 'buddy system' best practice in radiological work. From Fig. 1 and an initial review, the reader may believe that the risks are low and that passive components like pipes and heat exchangers do not pose hazards. Fission power plant experiences do not support this conclusion; there have been incidents that have caused extreme consequences and "near misses", meaning that no one was injured simply because they were not nearby when a failure occurred..$^{30-32}$ Overall, the risk values in Table I require interpretation since most of the individual events are low probability. The DOE Fusion Safety Standard ${ }^{33}$ has stated that workers shall be protected from routine industrial hazards to a level commensurate with that of comparable industrial facilities, and that fusion facilities shall comply with US Occupational Safety and Health Administration regulations to control industrial hazards.

Occupational safety data from a comparable industrial activity, in this case fission power, can be used as a comparison point to the WE-FMEA findings. The
US fission power industry has had a recent publication of occupational safety data, ${ }^{34}$ that were compiled by the US Institute of Nuclear Power Operations (INPO). Yearly aggregate values for lost work time injuries, injuries resulting in restricted work, and fatalities (combined under the term "accidents") for nuclear power plants have been given in Table II. However, the accident data are not divided into the same level of resolution as the predictions in Table I. As a first effort to allow a comparison, using past ratios of fatalities to injuries of $0.6 \%$ in the 1980 's ${ }^{35}$ and assuming a decrease to $0.45 \%$ in the 1990's and $2.3 \%$ from INPO data in the 2000's produces some results. As an initial point of comparison, the accident/injury $(\mathrm{MoI}+\mathrm{SI}+\mathrm{SeI}+\mathrm{CI})$ values are compared to the Table II worker accident risk value, and FI values are compared to the worker fatality risk value.

From Table I, this example task of one instrument calibration for one system gave a fatality probability of $4 \mathrm{E}-10$ over 4 hours, or a rate of $1 \mathrm{E}-10$ fatality/hour. From Table II, the overall five-year average for nuclear power plant workers performing all plant tasks is 5E-09 fatality per hour, thus the example task is $\sim 2 \%$ of the annual risk. The worker accident probability sum from the example task is $5 \mathrm{E}-06$ over 4 hours, or $1.25 \mathrm{E}-06 /$ hour; it is compared to the overall 5-year average for nuclear power plant worker accident/injury value of $1.4 \mathrm{E}-06 /$ hour. Thus the accident/injury risk from the example problem is about $89 \%$ of the five-year average worker accident rate. The example task results pose a quandary; quantification shows that the fatality risk of this one example task is reasonably low but that a single 4-hour task comprises almost all of the annual worker accident risk. It is possible that the injury severities have been overestimated or that some of the failure rates are conservatively large values; both would result in overestimating the risk. If further investigation revealed that the failure rates and injury severity assessment are reasonable, then other means to reduce worker risk should be employed. 
TABLE II. Worker risk in the US fission industry

\begin{tabular}{|c|c|c|}
\hline $\begin{array}{c}\text { Calendar } \\
\text { Year }\end{array}$ & $\begin{array}{c}\text { Accidents } \\
\text { per worker hour }\end{array}$ & $\begin{array}{c}\text { Fatalities } \\
\text { per worker hour }\end{array}$ \\
\hline 1980 & $1.05 \mathrm{E}-05$ & $6.30 \mathrm{E}-08$ \\
\hline 1984 & $7.50 \mathrm{E}-06$ & $4.50 \mathrm{E}-08$ \\
\hline 1988 & $6.70 \mathrm{E}-06$ & $4.02 \mathrm{E}-08$ \\
\hline 1990 & $5.15 \mathrm{E}-06$ & $2.32 \mathrm{E}-08$ \\
\hline 1992 & $3.85 \mathrm{E}-06$ & $1.73 \mathrm{E}-08$ \\
\hline 1994 & $3.20 \mathrm{E}-06$ & $1.44 \mathrm{E}-08$ \\
\hline 1996 & $2.30 \mathrm{E}-06$ & $1.04 \mathrm{E}-08$ \\
\hline 1998 & $1.45 \mathrm{E}-06$ & $6.53 \mathrm{E}-09$ \\
\hline 1999 & $1.70 \mathrm{E}-06$ & $7.65 \mathrm{E}-09$ \\
\hline 2000 & $1.30 \mathrm{E}-06$ & $3.90 \mathrm{E}-09$ \\
\hline 2001 & $1.20 \mathrm{E}-06$ & $3.60 \mathrm{E}-09$ \\
\hline 2002 & $1.10 \mathrm{E}-06$ & $3.30 \mathrm{E}-09$ \\
\hline 5 -yr average & $\sim 1.4 \mathrm{E}-06$ & $\sim 5 \mathrm{E}-09$ \\
\hline
\end{tabular}

This table assumes a 2,000 hour work year.

Data for 2001 and 2002 were taken from the INPO internet site.

Possible approaches are smart sensors that require less frequent calibration, ${ }^{36}$ such as every two years instead of each year, or a digital sensor that can be remotely calibrated. These solutions either reduce or avoid the worker 'at risk' time in the room. A risk-benefit analysis could address the increased sensor cost versus using the traditional sensor with yearly calibration.

\section{WE-FMEA LIMITATIONS}

Like every analysis method, the WE-FMEA has some limitations. The first limitation is that there can be some types of failure events that may be identified when examining the nearby components, but the failure events will not have failure rate data readily available. Some events will probably be very rare; they will not have any statistical data accumulated. In those cases, the WEFMEA can be used qualitatively to support hazard identification, or an effort can be made to estimate or bound the required failure rate. Other events may have failure rate data, but as seen in the example, the failure rates may be conservatively high - this may be acceptable in a system failure fault tree, but not so easily accepted in a personnel safety assessment. Another limitation is that assessing personnel injuries is very subjective, depending on the physics of a component failure event and the physics of energy interaction with a human being. There are a few published guidelines regarding human tolerances and injury thresholds, notably aerospace data, and the Federal Motor Vehicle Safety Standards for automobile passengers, found in 49CFR571. Such data require collection, assessment and development for application to the consequence assessment in the WEFMEA. While these institutions and the military have studied various aspects of human tolerances and injuries, injury prediction is not an exact science; for example, a test stand may have found that the force required to fracture a human bone is $1.1 \mathrm{kN}$, but if a smaller force from an impact is loaded at a detrimental orientation or at a focused point of impact, a bone can still be fractured. A final limitation is that the WE-FMEA is much like its parent FMEA, it is a tedious analysis; it is as time consuming as a system FMEA and requires a high level of knowledge about a variety of components and systems. Therefore, the WE-FMEA is not intended for application to every maintenance activity, only those activities taking place in the most complicated, congested or 'close quarters' parts of the facility where many types of hazards are co-located. This is a fitting limitation because in less congested areas of a facility, the primary hazards of the task at hand are expected to dominate the worker risk.

\section{CONCLUSIONS}

The WE-FMEA is a risk-based analysis tool that can support occupational safety assessment for complex work environments, such as magnetic or inertial fusion experiments, power plants, particle accelerators, or other complex, high-technology facilities. This new analysis method provides a systematic framework for assessing hazards that are proximate to the given task while existing approaches address only the hazards to be found within a given task. The WE-FMEA is to be used in concert with existing safety approaches, such as the JHA. The instrument calibration task used as a WE-FMEA example has shown that, with appropriate engineering component data and human injury data as support information, the WE-FMEA can be applied to fusion experiments and other facilities to estimate the worker risk from the secondary or 'peripheral' hazards. Secondary hazards can have the greatest influence on worker safety when the workers are following the JHA and adequately protecting themselves from the primary hazards of the task. Actuarial data from similar industries can serve as points of comparison to WE-FMEA results.

\section{ACKNOWLEDGMENTS}

This work was prepared for the US Department of Energy (DOE), Office of Fusion Energy Sciences, under the DOE Idaho Field Office contract number DE-AC0799ID13727.

\section{REFERENCES}

1. Job Hazard Analysis, OSHA 3071, US Occupational Safety and Health Administration, Washington DC (2002).

2. G. SWARTZ, Job Hazard Analysis, a guide to identifying risks in the workplace, Government Institutes Press, Rockville, Maryland (2001).

3. C. D. REESE, Accident/Incident Prevention Techniques, Routledge Publishers, New York (2001). 
4. L. LaFLAMME, T. BACKSTRÖM, and M. DÖÖS, "Typical accidents encountered by assembly workers: six scenarios for safety planning identified using multivariate methods," Accident Analysis and Prevention, 25, 399 (1993).

5. B. P. BLAYLOCK et al., U.S. Department of Energy Worker Health Risk Evaluation Methodology for Assessing Risks Associated with Environmental Restoration and Waste Management, ORNL-6833, Oak Ridge National Laboratory (1995).

6. A. R. MARCHESE and P. NEOGY, Trial Application of the Worker Safety Assessment Methodology, BNL-62727, Brookhaven National Laboratory (1995).

7. C. B. EVANS, Facility Worker Technical Basis Document, RPP-14286, CH2M Hill Hanford (2003).

8. G. T. KLOPP, "The Application of Risk Technology to Non-Nuclear, Hazardous Material Assessment at Nuclear Power Plants," Proceedings of the International Topical Meeting on Probabilistic Safety Assessment, (PSA 96), Park City, Utah, September 29 - October 3, 1996, volume II, American Nuclear Society, 1295 (1996).

9. L. HARMS-RINGDAHL, Safety Analysis: Principles and Practice in Occupational Safety, Taylor and Francis Publishers, London (2001).

10. D. H. STAMATIS, Failure Mode and Effect Analysis: FMEA from Theory to Execution, American Society for Quality Press, New York (2003).

11. NASA Safety Manual, NPR 8715.3, NASA Procedural Requirements, National Aeronautics and Space Administration, Washington, DC (January 2000).

12. Failure Mode and Effects Analysis in Health Care: Proactive Risk Reduction, Joint Commission on Accreditation of Healthcare Organizations, Oakbrook Terrace, Illinois (December 2002).

13. Guidelines for Failure Mode and Effects Analysis for Automotive, Aerospace, and General Manufacturing Industries, CRC Press, Boca Raton, FL (2003).

14. Guide for General Principles of Reliability Analysis in the Design and Operation of Safety Systems for Nuclear Power Generating Stations, ANSI/IEEE 352-1987, IEEE, New York (reaffirmed 1999).

15. T. PINNA et al., "Failure mode and effect analysis on ITER heat transfer systems," Fusion Engineering and Design, 42, 431 (1998).

16. The Abbreviated Injury Scale, Update 1998, Association for the Advancement of Automotive Medicine, Barrington, Illinois (1998)

17. L. C. CADWALLADER, "Preliminary Master Logic Diagram for Personnel Safety," Proceedings of the International Topical Meeting on Probabilistic Safety Assessment, (PSA '99), Washington DC, August 22-26, 1999, ANS, 1409 (1999).

18. Risk-Based Inspection Resource Document, API 581, American Petroleum Institute, Washington, DC, section 7 (2000).

19. S. A. EIDE, S. T. KHERICHA, M. B. CALLEY, and D. A. JOHNSON, "Component External Leakage and Rupture Frequency Estimates," Proceedings of the Probabilistic Safety Assessment International Topical Meeting (PSA '93), Clearwater Beach, FL, January 26-29, 1993, ANS, 1171 (1993).
20. A. RASHID et al., "Revised estimates of mortality from burns in the last 20 years at the Birmingham Burns Centre," Burns, 27, 723 (2001).

21. J. STILL et al., "Burns due to exposure to steam," Burns, 27, 379 (2001).

22. C. BALAKRISHNAN et al., "Burns and inhalation injury caused by steam," Burns, 22, 313 (1996)

23. E. M. KUHR, S. T. ROSE and K. S. CANADY, "Plant and Operator Response to an Extraction Steam Line Rupture Oconee Unit 2 - June 28, 1982," Proceedings of the Topical Meeting on Anticipated and Abnormal Plant Transients in Light Water Reactors, Jackson, Wyoming, September 26-29, 1983, Plenum Press, New York, 229 (1984).

24. J. P. BONGARRA, Jr., H. P. VANCOTT, R. F. PAIN, L. F. PETERSON, R. I. WALLACE, Human Factors Design Guidelines for Maintainability of Department of Energy Nuclear Facilities, UCRL-15673, LLNL (1985).

25. L. C. CADWALLADER, Selected Component Failure Rate Values from Fusion Safety Assessment Tasks, INEEL/EXT-98-00892, INEEL (1998).

26. L. C. CADWALLADER, Fire Protection System Operating Experience Review for Fusion Applications, INEL-95/0396, Idaho National Engineering Laboratory (1995).

27. J. P. POLOSKI et al., Rates of Initiating Events at U.S. Nuclear Power Plants: 1987-1995, NUREG/CR-5750, US Nuclear Regulatory Commission, Washington, DC (1999).

28. L. C. CADWALLADER, Ventilation Systems Operating Experience Review for Fusion Applications, INEEL/EXT99-001318, INEEL (1999).

29. D. E. PRICE, S. BRERETON, M. NEWTON, B. MOORE, D. MUIRHEAD, J. PARTRNAK, D. PROKOSCH, B. SPENCE, AND R. TOWLE, Latest Capabilities of PovRay Ricochet Tracker: Ricochet Flight Path Analysis \& Impact Probability Prediction Software, UCRL-JC-140361, Lawrence Livermore National Laboratory (2000).

30. Rupture of the Shell Side of a Feedwater Heater at the Point Beach Nuclear Plant, NRC Information Notice 1999. 19, US Nuclear Regulatory Commission, Washington DC (1999).

31. Main Feedwater Degradation in Safety-Related ASME Code Class 2 Piping Inside the Containment of a Pressurized Water Reactor, NRC Information Notice 200109, US Nuclear Regulatory Commission, Washington DC (2001).

32. Valve Body Erosion, NRC Information Notice 1989-01, US Nuclear Regulatory Commission, Washington DC (1989).

33. Safety of Magnetic Fusion Facilities: Requirements, DOESTD-6002-96, US Department of Energy, Washington, DC, May 1996.

34. "Statistics show U.S. Nuclear plants always improving," Nuclear News, 44, 38 (May 2001).

35. F. R. O'DONNELL AND H. C. HOY, Occupational Safety Data and Casualty Rates for the Uranium Fuel Cycle, ORNL-5797, Oak Ridge National Laboratory (1981).

36. H. M. HASHEMIAN, D. W. MITCHELL, K. M. PETERSEN, C. S. SHELL, Validation of Smart Sensor Technologies for Instrument Calibration Reduction in Nuclear Power Plants, NUREG/CR-5903, US Nuclear Regulatory Commission, Washington, DC (1993). 